\title{
Granite-hosted molybdenite mineralization from Archean Bundelkhand craton-molybdenite characterization, host rock mineralogy, petrology, and fluid inclusion characteristics of Mo-bearing quartz
}

\author{
J K PAti $^{1, *}$, M K PAnigrahi ${ }^{2}$ and M Chakarbortr ${ }^{1}$ \\ ${ }^{1}$ Department of Earth and Planetary Sciences, University of Allahabad, Allahabad 211 002, India. \\ ${ }^{2}$ Department of Geology and Geophysics, Indian Institute of Technology, Kharagpur 721 302, India. \\ *Corresponding author.e-mail: jkpati@gmail.com;jkpati@yahoo.co.in
}

The dominantly high-K, moderate to high $\mathrm{SiO}_{2}$ containing, variably fractionated, volcanic-arc granitoids ( \pm sheared) from parts of Bundelkhand craton, northcentral India are observed to contain molybdenite (Mo) in widely separated 23 locations in the form of specks, pockets, clots and stringers along with quartz \pm pyrite \pm arsenopyrite \pm chalcopyrite \pm bornite \pm covellite \pm galena \pm sphalerite and in invisible form as well. The molybdenite mineralization is predominantly associated with Bundelkhand Tectonic Zone, Raksa Shear Zone, and localized shear zones. The incidence of molybdenite is also observed within sheared quartz and tonalite-trondhjemite-granodiorite (TTG) gneisses. The fluid inclusion data show the presence of bi-phase $\left(\mathrm{H}_{2} \mathrm{O}-\mathrm{CO}_{2}\right)$, hypersaline and moderate temperature $\left(100^{\circ}-300^{\circ} \mathrm{C}\right)$ primary stretched fluid inclusions suggesting a possible hydrothermal origin for the Mo-bearing quartz occurring within variably deformed different granitoids variants of Archean Bundelkhand craton.

\section{Introduction}

The Archean Bundelkhand craton (hereinafter referred to as $\mathrm{ABC}$ ) is one of the five Archean cratons (Aravalli, Bastar, Bundelkhand, Dharwar, and Singhbhum) exposed in the peninsular shield that occupies an area of $\sim 29,000 \mathrm{~km}^{2}$ in northcentral India (figure 1). It is the least known for its granite-hosted mineral resources except for pyrophyllite and diaspore (Sharma 1979), gold mineralization (Pati et al. 1997) and recently discovered uranium content (Pathak et al. 2009) in the impact melt breccias of granitic composition from Dhala structure (Pati et al. 2008a). The incidences of molybdenite mineralization have been reported based on preliminary findings from the ABC (Shukla and Singh 1997; Nim and
Hasan 1997; Pati 1997; Pati and Panigrahi 2005). However, studies on molybdenite associated with copper-gold of Late Archean-Early Proterozoic age are very well known from Malanjkhand, Madhya Pradesh state, India (Panigrahi et al. 1993; Panigrahi and Mookherjee 1997; Stein et al. 2004; Pandit and Panigrahi 2012) from the adjacent Bastar craton. Molybdenite associated mineral deposits from India and other parts of the world are known to be good indicators of geodynamic settings (Sillitoe 1972; Panigrahi and Mookherjee 1997; Corbett and Leach 1998; Santosh 1999; Richards 2003; Hou et al. 2009) and molybdenite is extensively used to date the mineralization event (Santosh 1988a, b; Mao et al. 1999; Stein et al. 1997, 2004; Stein 2006;

Keywords. Molybdenite; granitoids; fluid inclusion; Bundelkhand Tectonic Zone; Bundelkhand craton. 

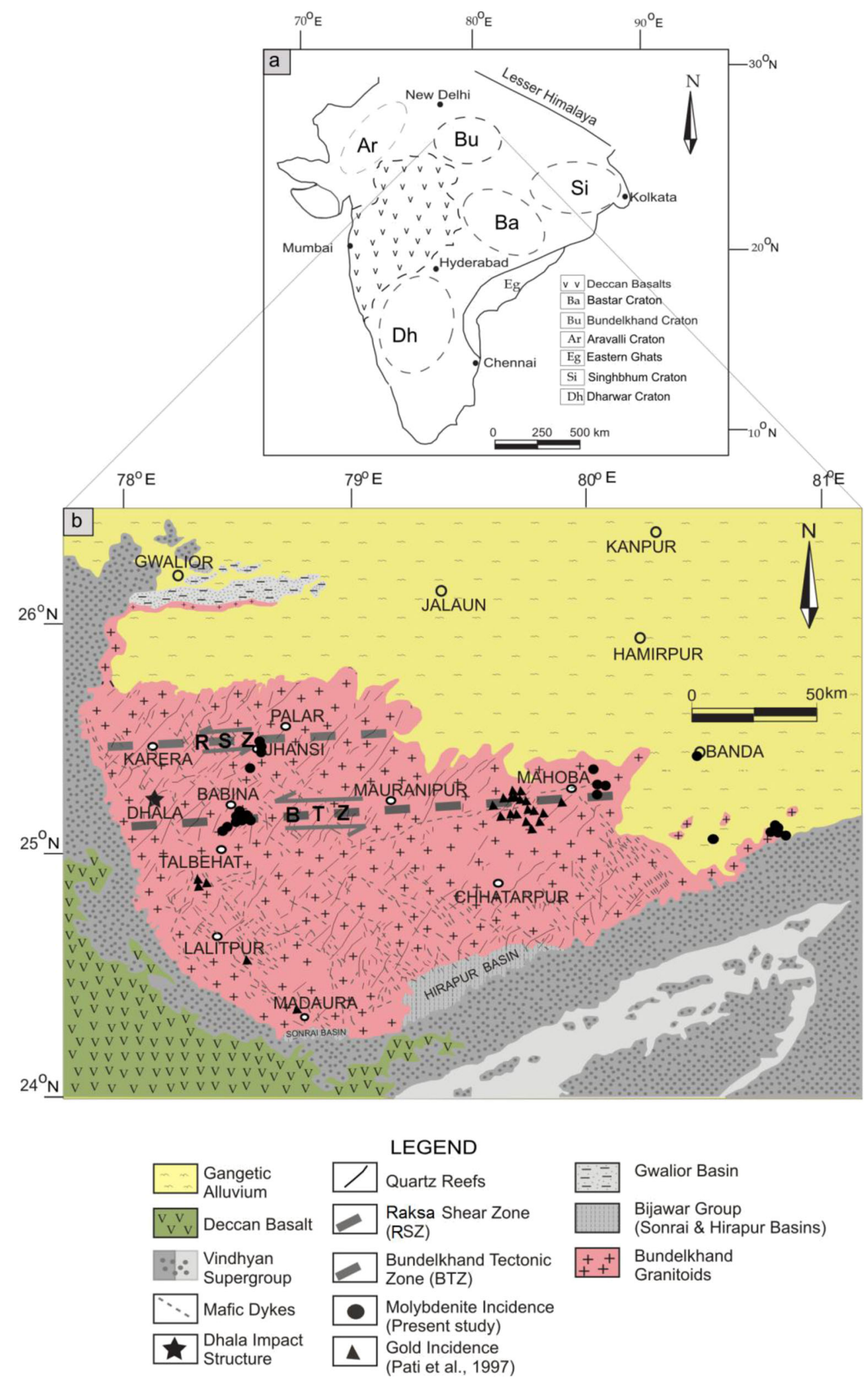

Figure 1. A simplified map of Bundelkhand craton showing regional geology, locations of Mo-bearing rocks (solid dots), Au incidences (solid triangles; after Pati et al. 1997), Raksa Shear Zone (RSZ) and Bundelkhand Tectonic Zone (BTZ).

Li et al. 2011; Delibaş and Genç 2012). Here, we present a detailed report on molybdenite mineralization from parts of the ABC with host rock mineralogy and petrology and the first fluid inclusion data from Mo-bearing quartz from granitoids. 


\section{Geology and geochronology of Archean Bundelkhand craton (ABC)}

The ABC comprises mainly granitoids (including TTG; Sharma and Rahman 1995). The metasupracrustal rocks comprise banded iron formations (BIF), ultra high pressure (UHP) corundum-bearing phengite schist (Saha et al. 2010), inter-bedded quartzites, calc-silicate gneisses, metamorphosed ultramafic rocks of komatiitic affinity (similar to modern boninites; Malviya et al. 2006), amphibolites, metamorphosed pillow lavas, and volcaniclastic metasediments. These metasupracrustal slivers occurring in variably deformed granitoids are inferred to be the remnants of supra-subduction crust tectonically emplaced during Archean arc-continent-continent collision (Malviya et al. 2006). The temporally distinct tectonically controlled multiple phases of silicothermal fluid activity resulting in NNE-SSW to NE-SW trending quartz veins within granitoids and supracrustals are the most conspicuous linear to curvilinear features observed in the ABC (Pati et al. 2007). These veins are in turn intruded by NW-SE trending mafic dykes of tholeiitic affinity (Pati et al. 2008b). The pink to grey coloured, porphyritic granitoids in the ABC include syeno- and monzogranite, granodiorite, diorite, alkali feldspar syenite, granite porphyry and rhyolite (Sarkar et al. 1984; Rahaman and Zainuddin 1993; Mondal et al. 2002; Pati et al. 2007, 2008a, b). They are typically metaluminous-peraluminus, alkaline to calc-alkaline, volcanic-arc granitoids and show LREE-enriched and HREE-depleted pattern with a negative Eu anomaly.

The metamorphic evolution of the Bundelkhand craton is poorly constrained. Basu (1986) reported greenschist to amphibolite facies metamorphism for the basement gneisses and schists, whereas Saha et al. (2010) reported eclogite facies condition with peak $\mathrm{P}-\mathrm{T}$ of $20 \mathrm{kbar}$ and $650^{\circ} \mathrm{C}$ for margarite-phengitic muscovite-chlorite corona mantled corundum-bearing quartz-free high-Mg, Al phlogopite-chlorite schists intruded by $3.2-$ 3.4 Ga old TTG.

$\mathrm{The} \mathrm{Pb}-\mathrm{Pb}$ isochron ages of zircons determined by Ion Probe and SHRIMP techniques from some of the Bundelkhand granitoids range from 2492 to $2551 \mathrm{Ma}$ in rhyolite/granophyre/granite porphyry and $2563 \pm 6 \mathrm{Ma}$ in diorite (Mondal et al. 2002; Pati et al. 2010) and are suggested to be the stabilization age of the craton (Mondal et al. 2002). Pati et al. (2010) have dated the zircons from the granitoids from NW parts of Bundelkhand craton by SHRIMP dating techniques and reported ages of 2563 and 2553 Ma.

Zircons from the basement gneiss-greenstone components yield ${ }^{207} \mathrm{~Pb} /{ }^{206} \mathrm{~Pb}$ age of $3270 \pm 3 \mathrm{Ma}$
(Mondal et al. 2002). The NW-trending mafic dykes post-date the giant quartz veins emplacement (Pati et al. 2007) and shear zone development (Basu 1986; Pati et al. 1997; Mondal and Ahmad 2001). Based on ${ }^{40} \mathrm{Ar} /{ }^{39} \mathrm{Ar}$ step heating ages, Rao et al. (2005) infer two phases of mafic dyke intrusion at 2000 and $2150 \mathrm{Ma}$ although the inferences drawn are incorrect (Pati et al. 2010). These ages partly overlap with $\mathrm{Rb}-\mathrm{Sr}$ isochron ages (2130 and $2402 \mathrm{Ma}$ ) from granitoids and tonalitetrondhjemite-granodiorite (TTG) suites (Sarkar et al. 1994, 1996).

The granitoids are traversed by regional eastwest trending subvertical sinistral shear zones (figure 1), e.g., Raksa Shear Zone ( 50 m wide; Senthiappan 1976, 1981) and Bundelkhand Tectonic Zone ( up to $2 \mathrm{~km}$ thick; Pati 1998, 1999; Malviya et al. 2006; Pati et al. 2007, 2008b; Saha et al. 2010; Gokarn et al. 2013). The Bundelkhand Tectonic Zone has now been established as an Archean subduction zone (Malviya et al. 2006; Saha et al. 2010). Recent geochronological studies based on Ar-Ar step ages in parts of Bundelkhand craton have indicated the imprints of two possible hydrothermal/thermal events, at ca. 0.6 and ca. $1 \mathrm{Ga}$, synchronous with Pan-African and Grenvillian orogenies, respectively (Pati et al. 2010).

\section{Mo mineralization in Archean Bundelkhand craton}

The presence of Mo is observed in 23 locations during the present study in parts of Bundelkhand craton (figure 1). The majority of the Mo incidences cluster around 25 $15^{\prime}$ (Bundelkhand Tectonic Zone) similar to gold mineralization reported by the first author earlier (Pati et al. 1997). However, some are observed in the vicinity of Raksa Shear Zone and others are associated EWtrending localized shear zones around Banda and Rauli Kalyanpur. Their strike continuities have not been mapped. The Mo mineralization in ABC mainly occurs as incidences in the form of films along shear planes (figure 2a), specks (figure 2b), stringers, pockets, and clots (table 1). Mo with or without other sulphide phases occurs in the visible form as massive clots (figure 2c), disseminated type (figure 2d), and as invisible type (mainly identified on the basis of oxidation haloes and/or brown coloured solution imprints; figure 2e). Mo films with Ccp are noted along the foliation surfaces of sheared granites (figure 2f). The disseminated types are observed in mediumgrained granite associated with quartz. In Gonda area (table 1), Mo is found in the vicinity of a mesoscopic shear associated with Ccp. The massive Mo variety is mostly found in granite pegmatite veins intruding into the hornblende granite. 


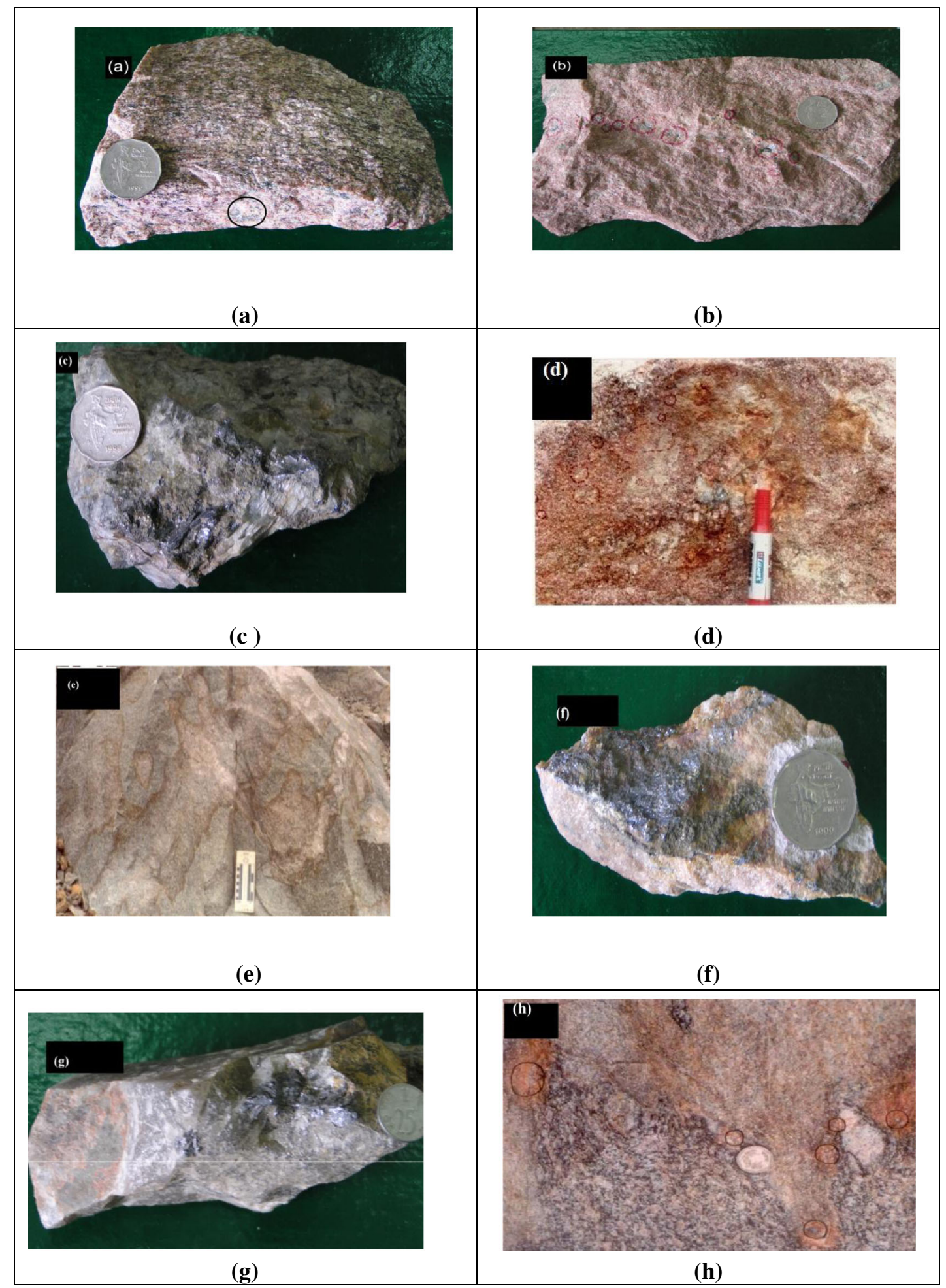

Figure 2. (a) Mylonitized pink granitoid with brownish haloes across the foliation and Mo films (open circle) occurring along the foliation surface are observed in this sample. The coin diameter is $2.5 \mathrm{~cm}$. (b) Medium-grained pink granite (red circles) shows the presence of Mo in a linear pattern as clots. The coin diameter is $2.5 \mathrm{~cm}$. (c) Mo with Py is seen to occur in quartz + feldspar-bearing granite pegmatite. The coin diameter is $2.5 \mathrm{~cm}$. (d) An outcrop showing a mediumgrained pink granitoid with disseminated Mo-specks (encircled with red pen; pen cap length: $3 \mathrm{~cm}$ ) and brownish yellow oxidation haloes. (e) Medium-grained grey granitoid with brown coloured solution seams (after Mo) is seen pervasively in this outcrop. The molybdenite is only encountered in geochemical analysis. (f) Mo vein is exposed in a broken surface of medium-grained sheared pink granite. The coin diameter is $2.5 \mathrm{~cm}$. (g) The massive Mo phase is seen to occur as clots in quartz without any other sulphide phase from a granite pegmatite rock. The coin diameter is $2.5 \mathrm{~cm}$. (h) The molybdenite with brown oxidation haloes is seen to occur close to the interface of an intrusive contact between medium-grained pink granite and hornblende-bearing coarse-grained porphyritic granodiorite. 


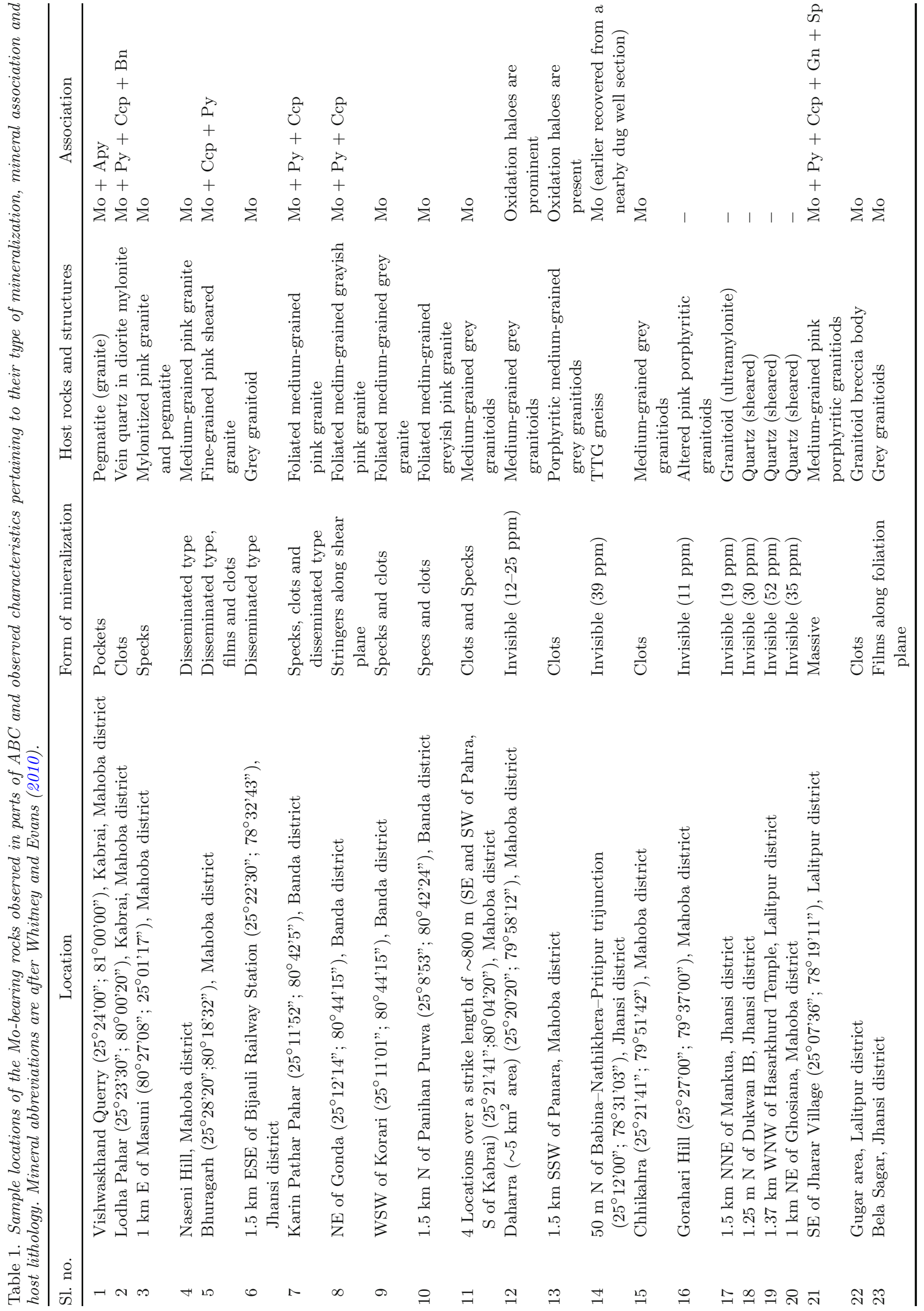




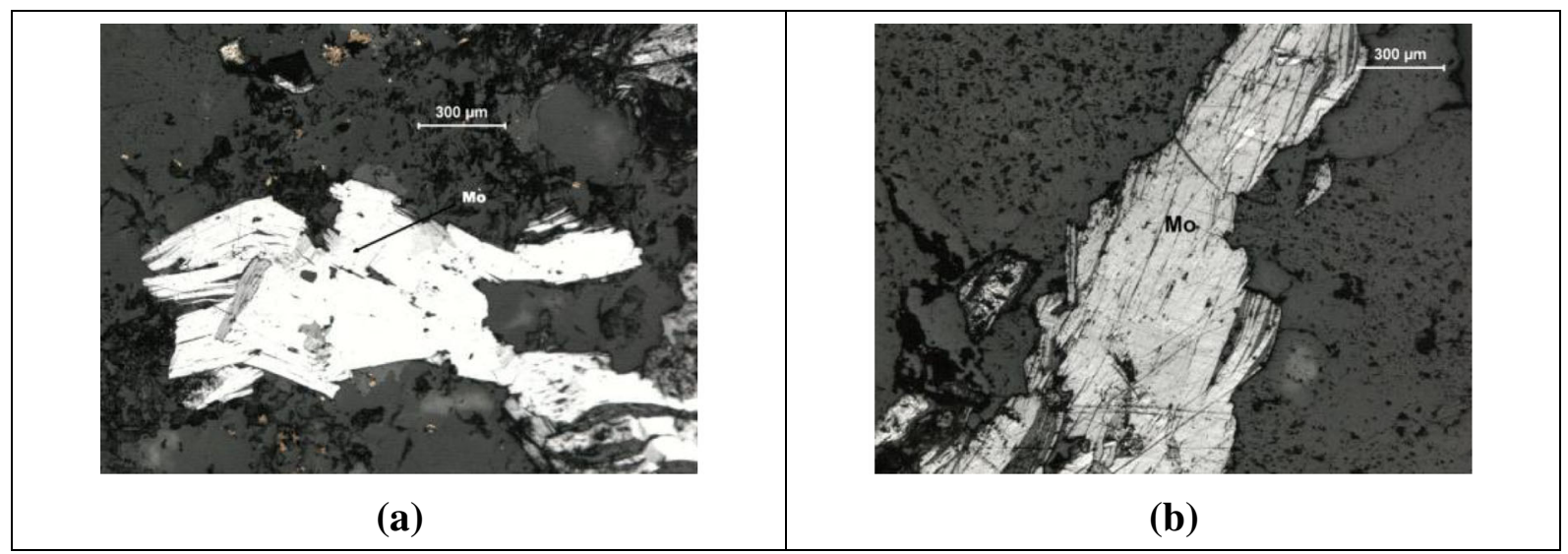

Figure 3. (a and b) Representative photomicrographs obtained using plane polarized light in reflected light mode shows aggregates of molybdenite flakes in samples BHU-1 and BGM-9, respectively. In (a) majority of the grains are in the minimum absorption position (with a couple of them in orthogonal orientation). In (b) the grains are all in the maximum absorption (minimum reflectance) position. These aggregates of molybdenite flakes occur intimately associated with quartz within intergranular spaces as well as fracture fillings.

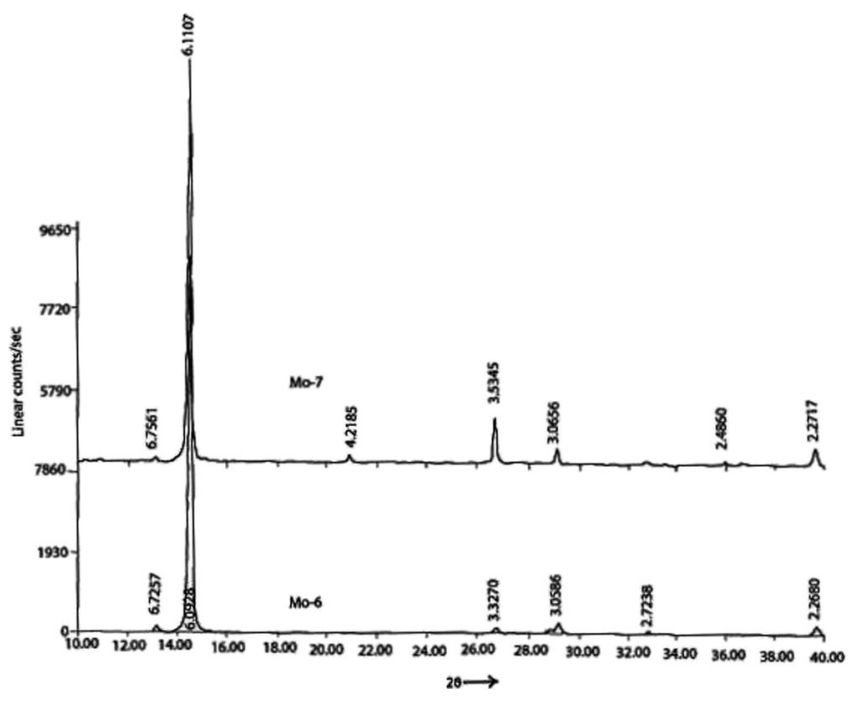

Figure 4. X-ray patterns of two representative samples (Mo-6 and Mo-7) using $\mathrm{CuK} \alpha$ radiation between $10^{\circ}$ and $40^{\circ}(2 \theta)$ confirming the presence of molybdenite.

This variety is either observed within greasy quartz phase (figure $2 \mathrm{~g}$ ) occurring within pegmatite or in contact with hornblende granite with or without $\mathrm{Py} \pm \mathrm{Ccp}$. The clots are seen in biotite granite and along the contact between leucogranite and hornblende granite (figure $2 \mathrm{~h}$ ). The other associated sulphide phases observed include Py, Ccp, Bn and $\mathrm{Cv}$ (figure 2e) in Daharra-Pahara area. The mineralization is mostly localized except for the outcrop in Daharra-Pahara area.

\section{Molybdenite characterization}

Molybdenite is identified as bluish-grey coloured, very soft mineral having a metallic luster and greenish grey streak. It is flaky in nature and easily peels off with pocket knife. Microscopic study shows euhedral to subhedral flaky aggregates with high reflectivity and blue anisotropism (figure $3 \mathrm{a}, \mathrm{b}$ ). The molybdenite flakes with one set of cleavage are intimately associated with quartz occurring within intergranular spaces as well as fracture filling. Other sulphide phases associated, wherever present, were physically separated under a stereozoom microscope and only molybdenite was analyzed by X-ray diffraction technique. Sulphide phases, in general, were analyzed by Electron Probe Micro-Analyzer (EPMA).

\section{$4.1 X$-ray diffraction of molybdenite}

Five molybdenite samples were separated under the microscope and analyzed by X-ray diffraction technique (Seifert X-ray Diffractometer, Lucknow University, India) using $\mathrm{CuK} \alpha$ target and $\mathrm{Ni}$ filter and the $40 \mathrm{kV} / 30 \mathrm{~mA}$ operating condition. The calibration was carried out using Silicon standard. The major peaks at $2 \theta\left(14.48,44.22\right.$ and $\left.49.95^{\circ}\right)$ corresponding to their respective characteristic dspacings $(6.11,2.05$ and $1.83 \AA$ ) were observed (figure 4). Mo occurs with or without other sulphide phases like pyrite (Py), arsenopyrite (Apy), chalcopyrite $(\mathrm{Ccp})$, bornite $(\mathrm{Bn})$, covelite $(\mathrm{Cv})$, sphalerite (Sp) and galena (Gn) (Pati 1997; Shukla and Singh 1997; Nim and Hasan 1997).

\subsection{Mineral chemistry of rock- and ore-forming minerals}

The rock-forming minerals like feldspar, biotite, hornblende, muscovite, chlorite, sphene and epidote and ore-forming phases (Mo, Py, Ccp, Cv and $\mathrm{Bn}$ ) were analyzed using Cameca Camebax 
SX-51 system at the EPMA Laboratory of GSI, Faridabad. The presence of other reported sulphide phases ( $\mathrm{Sp}$ and $\mathrm{Gn}$ ) were not observed in the samples analyzed in this study. The analyses are summarized in table 2. Calibration is done using standards like natural silicate and oxide mineral from the BRGM, France and the data reduction is carried out after applying PAP correction (Pouchou and Pichoir 1985). Beam current and accelerating voltage were maintained at $20 \mathrm{nA}$ and $15 \mathrm{kV}$, respectively.

The Mo-bearing granitoids show evidences of potassic alteration (secondary K-feldspar with secondary biotite associated with chlorite), phyllic alteration (vein quartz, sericite after feldspar chlorite and pyrite) and propylitic alteration (epidote, chlorite, calcite, sericite, and quartz). The feldspar composition is predominantly orthoclaserich $\left(\mathrm{Cn}_{1.4-1.8} \mathrm{Or}_{93.8-96} \mathrm{Ab}_{2.5-4.4}\right)$ with significant barium molecule (Cn: celsian) and nearly pure albitic-end members $\left(\mathrm{Or}_{0.7} \mathrm{Ab}_{97.6} \mathrm{An}_{1.7}\right)$ are also present. In addition, both alkali feldspars and plagioclase $\left(\mathrm{Or}_{0.5} \mathrm{Ab}_{82.8} \mathrm{An}_{16.7}\right)$ feldspars are observed.
Predominantly the Mo-bearing granitoids of ABC are essentially two feldspar (sub-solvus; low temperature) granitoids. Biotite is Fe-rich $\left(\mathrm{Fe}_{2.89}\right)$ whereas chlorite contains only $\mathrm{Mg}_{2.79}$ and is devoid of iron. Muscovite contains 2.19 wt.\% total iron. Sphene has substantial titanium $\left(\mathrm{Ti}_{0.80}\right)$. The oreforming minerals analyzed include $\mathrm{Mo}, \mathrm{Py}, \mathrm{Ccp}, \mathrm{Bn}$ and $\mathrm{Cv}$. Mo is nearly pure with trace of iron $(\mathrm{Mo}=$ 60.65-61.58 wt.\%). The Au content in molybdenite should be ignored as the BRGM (France) Mo standard was Au-bearing. Presence of Py ( \pm Apy), Ccp (with Mo), and $\mathrm{Cv}$ (with Mo) have also been confirmed.

\section{Petrology of molybdenite-bearing granitoids and related rocks}

\subsection{Petrography}

The Mo occurs in variably deformed different petrological variants of granitoids. They include granitic pegmatites, coarse grained pink porphyritic

Table 2. The representative EPMA mineral analysis of rock-forming phases in Mo-bearing rocks in ABC. Mineral abbreviations are after Whitney and Evans (2010).

\begin{tabular}{|c|c|c|c|c|c|c|c|c|c|c|}
\hline Mineral/oxide & Fs & Fs & Fs & Fs & $\mathrm{Bt}$ & Ms & Chl & Spn & Mag & $\mathrm{Ep}$ \\
\hline $\mathrm{SiO}_{2}$ & 68.34 & 64.16 & 64.71 & 63.84 & 37.30 & 47.32 & 25.05 & 29.38 & 0.13 & 37.42 \\
\hline $\mathrm{TiO}_{2}$ & 0.20 & 0.00 & 0.00 & 0.00 & 2.59 & 0.04 & 0.11 & 31.23 & 0.09 & 0.07 \\
\hline $\mathrm{Al}_{2} \mathrm{O}_{3}$ & 20.20 & 22.77 & 18.86 & 18.79 & 15.66 & 37.18 & 20.02 & 4.84 & 0.00 & 22.21 \\
\hline $\mathrm{Cr}_{2} \mathrm{O}_{3}$ & - & - & - & - & 0.10 & 0.10 & - & - & 0.05 & 0.02 \\
\hline $\mathrm{Fe}_{2} \mathrm{O}_{3}$ & 0.08 & 0.07 & 0.04 & 0.00 & 22.48 & 2.19 & 33.45 & 1.94 & 99.94 & 14.49 \\
\hline $\mathrm{MnO}$ & - & - & - & - & 0.83 & 0.00 & 1.50 & - & 0.01 & 0.19 \\
\hline $\mathrm{MgO}$ & 0.01 & 0.05 & 0.01 & 0.00 & 7.60 & 0.02 & 8.56 & 0.08 & 0.00 & 0.03 \\
\hline $\mathrm{BaO}$ & 0.04 & 0.00 & 0.83 & 0.96 & 0.02 & 0.10 & - & - & - & - \\
\hline $\mathrm{CaO}$ & 0.36 & 3.53 & 0.00 & 0.00 & - & 0.00 & 0.14 & 26.54 & - & - \\
\hline $\mathrm{Na}_{2} \mathrm{O}$ & 11.03 & 9.68 & 0.34 & 0.48 & 0.03 & 0.28 & 0.08 & 0.10 & - & - \\
\hline $\mathrm{K}_{2} \mathrm{O}$ & 0.10 & 0.09 & 15.11 & 15.38 & 9.15 & 8.24 & 0.05 & 0.02 & - & - \\
\hline $\mathrm{H}_{2} \mathrm{O}^{\mathrm{C}}$ & - & - & - & - & 3.89 & 4.57 & 10.95 & 0.72 & - & 0.93 \\
\hline Total & 100.16 & 100.32 & 99.90 & 99.46 & 99.64 & 99.99 & 99.90 & 94.84 & 100.20 & 98.67 \\
\hline $\mathrm{Si}$ & 2.977 & 2.821 & 2.990 & 2.977 & 5.742 & 6.201 & 5.483 & 1.000 & 0.005 & 0.005 \\
\hline $\mathrm{Al}$ & 1.022 & 1.180 & 1.027 & 1.033 & & & & 0.194 & 0.000 & 0.000 \\
\hline $\mathrm{Al}^{\mathrm{IV}}$ & & & & & 2.258 & 1.799 & 2.517 & & & \\
\hline $\mathrm{Al}^{\mathrm{VI}}$ & & & & & 0.582 & 3.944 & 2.648 & & & \\
\hline $\mathrm{Fe}^{3}$ & 0.002 & 0.002 & 0.001 & 0.000 & & & & 0.007 & 1.984 & 1.984 \\
\hline $\mathrm{Fe}^{2}$ & & & & & 2.894 & 0.240 & & 0.043 & 1.007 & 1.007 \\
\hline $\mathrm{Ti}$ & 0.001 & 0.000 & 0.000 & 0.000 & 0.300 & 0.003 & 0.018 & 0.799 & 0.002 & 0.002 \\
\hline $\mathrm{Mg}$ & 0.001 & 0.003 & 0.001 & 0.000 & 1.744 & 0.004 & 2.792 & 0.004 & 0.000 & 0.000 \\
\hline $\mathrm{Na}$ & 0.931 & 0.825 & 0.031 & 0.043 & 0.010 & 0.072 & 0.035 & 0.007 & & \\
\hline $\mathrm{Ca}$ & 0.017 & 0.166 & 0.000 & 0.000 & 0.000 & 0.000 & 0.032 & 0.968 & & \\
\hline K & 0.006 & 0.005 & 0.891 & 0.915 & 1.796 & 1.377 & 0.014 & 0.001 & & \\
\hline $\mathrm{Ba}$ & 0.001 & 0.000 & 0.015 & 0.018 & 0.001 & 0.005 & & & & \\
\hline $\mathrm{Cn}$ & 0.001 & 0.000 & 0.014 & 0.018 & & & & & & \\
\hline Or & 0.006 & 0.005 & 0.960 & 0.938 & & & & & & \\
\hline $\mathrm{Ab}$ & 0.976 & 0.828 & 0.025 & 0.044 & & & & & & \\
\hline An & 0.017 & 0.167 & 0.000 & 0.000 & & & & & & \\
\hline
\end{tabular}


granitoids, medium grained grey granitoids, medium grained pink granitoids, and TTG mainly. However, Mo is noted in trace amount in sheared quartz also. The Mo-bearing rocks are in general holocrystalline, inequigranular, and medium-to-coarse grained (barring a pegmatitic variant). The minerals observed are: quartz (Qz), microcline $(\mathrm{Mc})$, perthite, plagioclase $(\mathrm{Pl})$, biotite $(\mathrm{Bt})$, apatite $(\mathrm{Ap})$, zircon (Zrn), sphene (Spn), ilmenite (Ilm), magnetite (Mgt), chlorite (Chl), epidote (Ep), sericite (Ser), opaque phase, and calcite (Cal). Qz phenocrysts are anhedral, invariably show undulose extinction and serrated grain boundaries with subgrain development (figure 5a). In places, ribbon Qz is also observed. $\mathrm{Pl}$ phenocrysts are subhedral to anhedral and invariably altered. Mc and perthite are mostly subhedral and relatively fresh. Bt are subhedral, prismatic, straw yellow to dark yellowish brown pleochroism and in places contain pleochroic halos as well. Spn with subhedral to euhedral shapes occurs mostly in the boundary between Bt and Ilm, possibly as a reaction product. A fabric development in granitoids is very clear (figure $5 \mathrm{~b}$ ) which is either defined by $\mathrm{Qz}$ or Bt. The modal \% of Qz (50-60), Or (40-30) and Pl (20-10) observed in Mo-bearing granitoids is variable.

\subsection{Petrochemistry}

The major and trace element analyses of $23 \mathrm{Mo-}$ bearing rock samples and REE contents of eight samples are furnished in table 3. The samples were analyzed using XRF, ICP-AES, and INAA for their major, trace, and REE contents, respectively. The details of analytical methods, instruments, and calibrations are summarized in Pati et al. (2008b). The Mo-bearing granitoids of ABC with $\mathrm{SiO}_{2}$ content between 68.18 and 76.41 wt.\% (avg. 74.37; SD = 2.17) are fresh with LOI (loss on ignition) varying from 0.28 to $1.43 \mathrm{wt} . \%$ with mean value of 0.72 wt.\% (figure $6 \mathrm{a}$ ). The total alkali values range between 6.37 and 9.66 wt.\% (avg.

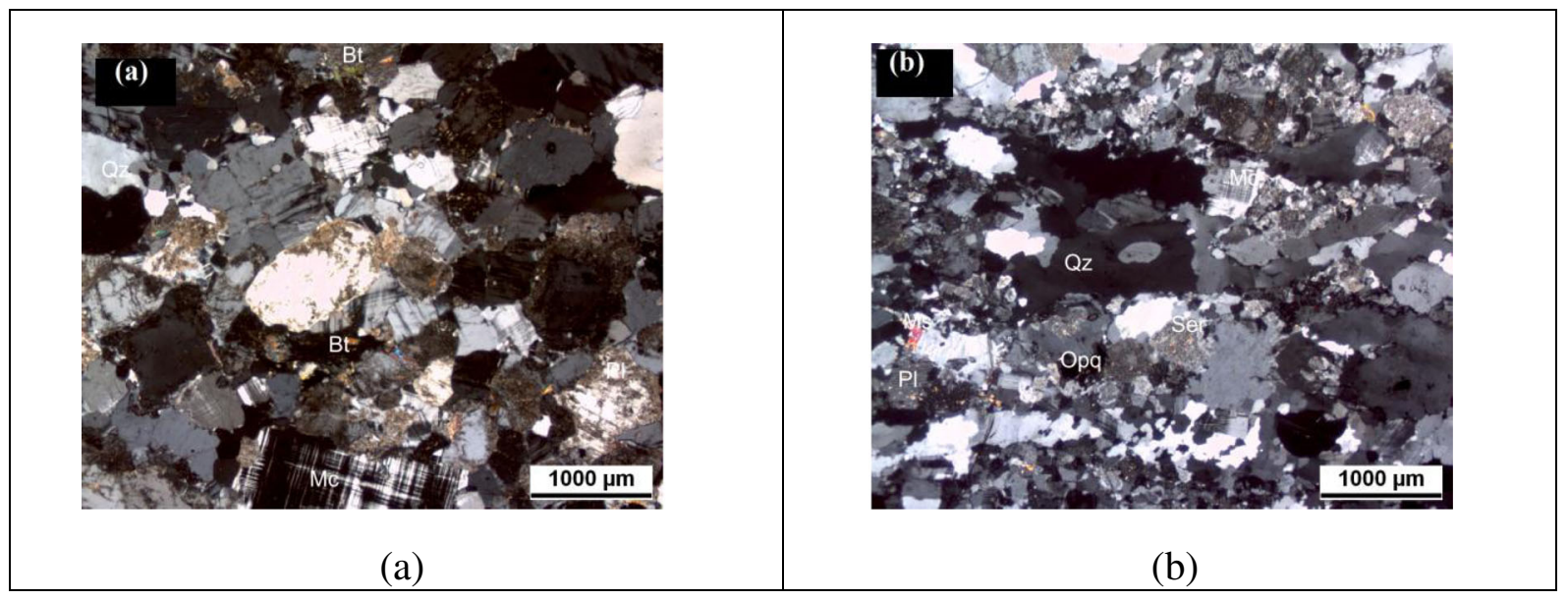

Figure 5. (a) Mo-bearing granitoid defined by phanerocrystalline anhedral texture and typical minerals (perthite + Qz + $\mathrm{Pl}+\mathrm{Mc}+\mathrm{Ser}$ ) with a trace amount of $\mathrm{Bt}+\mathrm{Opq} . \mathrm{Pl}$ is partly altered and Mc is unaltered. (b) Mo-bearing sheared granitoid with perthite $+\mathrm{Qz}+\mathrm{Pl}+\mathrm{Mc}+\mathrm{Ms}+\mathrm{Ser}$ ) with a trace amount of Opq. Qz grains show serrated grain boundaries, subgrain development and defines a penetrative fabric.

Table 3. Representative EPMA analyses of sulphide phases in Mo-bearing rocks in ABC. Mineral abbreviations are after Whitney and Evans (2010).

\begin{tabular}{|c|c|c|c|c|c|c|c|c|c|}
\hline Mineral/element & Mo & Mo & Mo & Mo & Mo & $\mathrm{Py}$ & $\mathrm{Py}$ & Ccp & $\mathrm{Cv}$ \\
\hline S & 35.62 & 35.91 & 36.47 & 37.06 & 35.87 & 53.57 & 53.11 & 35.47 & 21.24 \\
\hline $\mathrm{Fe}$ & 0.93 & 0.84 & 0.00 & 0.05 & 0.00 & 45.74 & 46.72 & 29.48 & 0.89 \\
\hline $\mathrm{Cu}$ & 0.00 & 0.00 & 0.05 & 0.00 & 0.00 & 0.05 & 0.00 & 33.89 & 74.78 \\
\hline $\mathrm{Zn}$ & 0.04 & 0.00 & 0.04 & 0.00 & 0.04 & 0.03 & 0.00 & 0.00 & 0.02 \\
\hline As & 0.00 & 0.00 & 0.01 & 0.00 & 0.00 & 0.11 & 0.00 & 0.00 & 0.00 \\
\hline Mo & 60.65 & 61.17 & 61.58 & 60.87 & 60.94 & 0.62 & 0.60 & 0.41 & 0.35 \\
\hline $\mathrm{Ag}$ & 0.00 & 0.09 & 0.00 & 0.00 & 0.00 & 0.00 & 0.00 & 0.08 & 0.00 \\
\hline $\mathrm{Au}$ & 0.36 & 0.51 & 0.22 & 0.53 & 0.44 & 0.03 & 0.00 & 0.00 & 0.00 \\
\hline Total & 97.60 & 98.52 & 98.37 & 98.51 & 97.28 & 100.16 & 100.44 & 99.34 & 97.29 \\
\hline
\end{tabular}


7.99; $\mathrm{SD}=0.84)$ whereas the $\mathrm{K}_{2} \mathrm{O} / \mathrm{Na}_{2} \mathrm{O}$ ratios lie between 0.43 and 2.09 (avg. 1.32; $\mathrm{SD}=0.47$ ) with six compositions having $\mathrm{Na}_{2} \mathrm{O}>\mathrm{K}_{2} \mathrm{O}$. The $\mathrm{Al}_{2} \mathrm{O}_{3}$ content in these samples lies within a restricted range (11.70-14.75 wt.\%; avg. 12.79; $\mathrm{Sd}=0.83)$. They contain primary magnetite
$\left(\mathrm{Fe}_{2} \mathrm{O}_{3}^{T}: 0.47-4.6\right.$ wt.\%; avg. 1.72; $\left.\mathrm{Sd}=1.08\right)$ with or without sphene. All major oxides barring $\mathrm{K}_{2} \mathrm{O}$ show a decreasing trend with increasing $\mathrm{SiO}_{2}$ (figure $6 \mathrm{~b}-\mathrm{g}$ ) and the granitoids can be categorized into three broad groups within $\sim 8$ wt. $\mathrm{SiO}_{2}$. The compositions are metaluminous to peraluminous

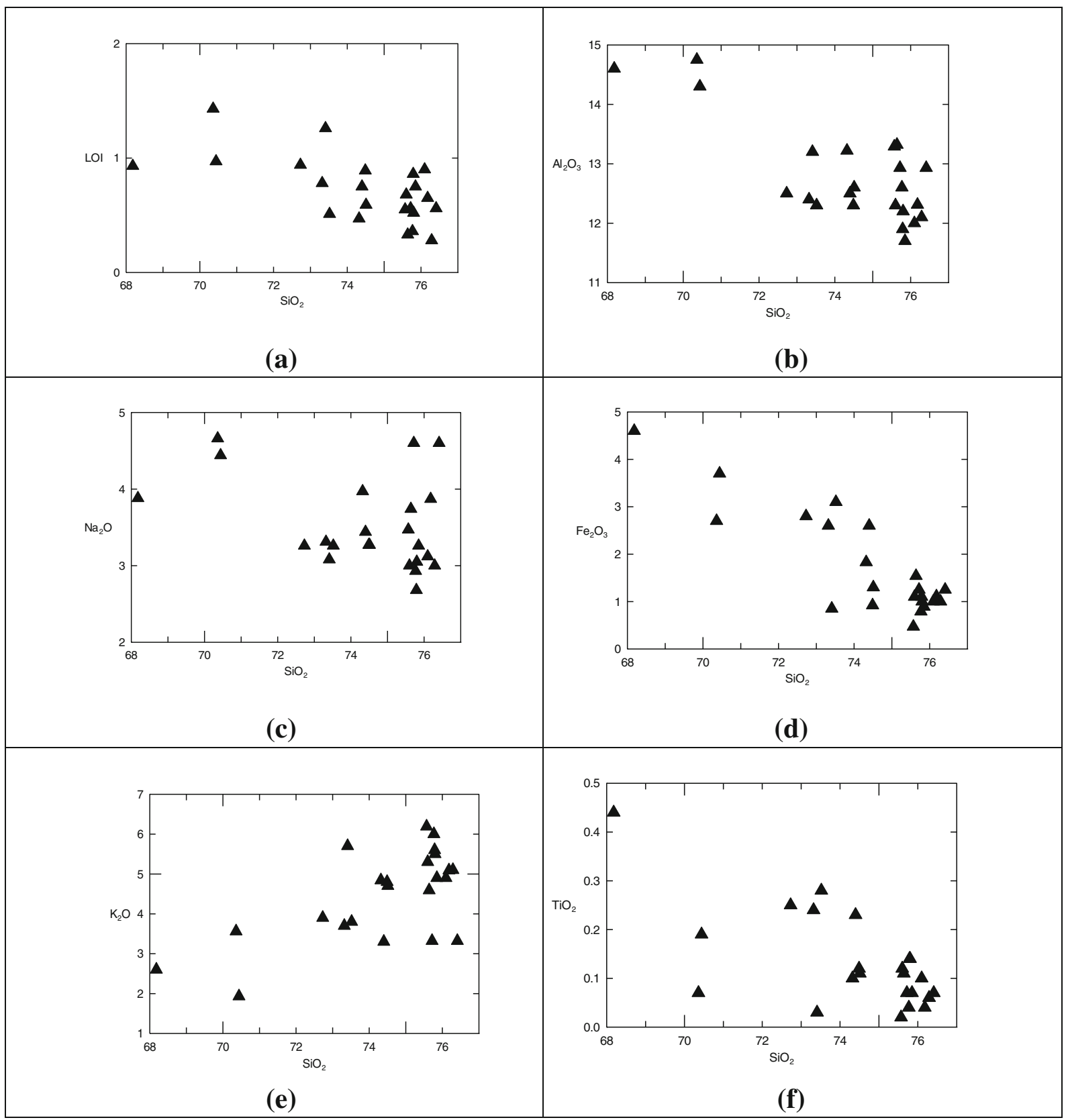

Figure 6. (a) The LOI (loss on ignition) is minimal suggesting their largely unaltered nature in general. (b-g) Harkar type variation diagrams of Mo-bearing rocks showing the variability of various oxides with respect to their respective $\mathrm{SiO}_{2}$ contents. (h) The plot (Shand's index after Maniar and Piccoli 1989) shows the Mo-bearing rocks to metaluminous to peraluminous in nature. (i) The normative analysis of Mo-bearing rocks are plotted in terms of quartz-albite-K-feldspar (Q-Ab-Or) and the eutectic composition from various experimental runs are also plotted (redrawn after Winter 2001). (j) $\mathrm{Ta}-\mathrm{Yb}$ (after Pearce et al. 1984) shows that the Mo-bearing granitoids of the ABC are volcani arc granitoids (VAG). (k) The primitive mantle normalized multication parameter diagram (after Sun and McDonough 1989) shows the Mobearing granitoids to have high $\mathrm{Th}, \mathrm{Pb}, \mathrm{K}$ and La contents and characteristically depleted in $\mathrm{Nb}$, Ta and Ti. (l) The chondrite normalized REE pattern (after Sun and McDonough 1989) shows a typical LREE-enriched, HREE depleted and varied Eu-anamaly. 


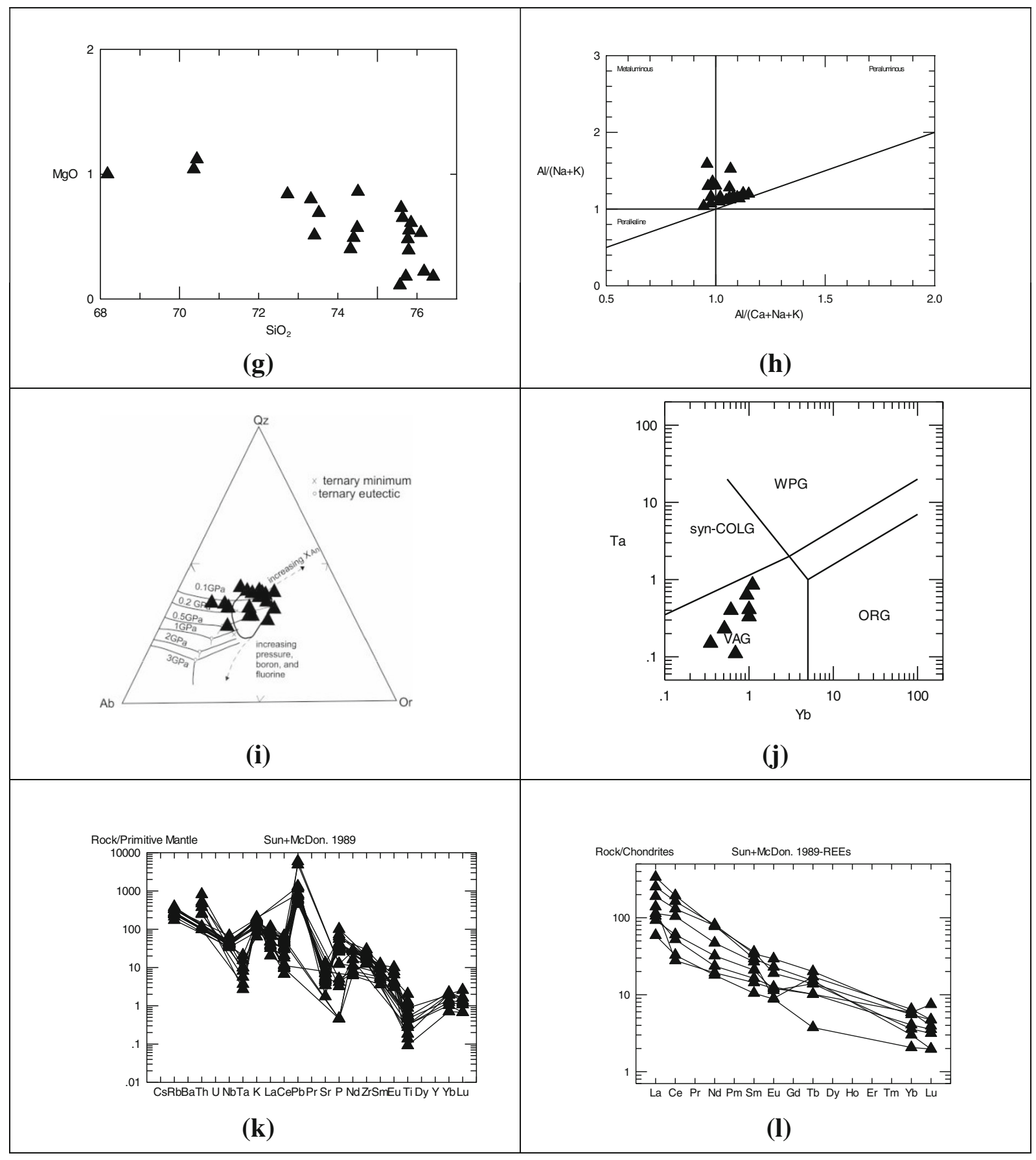

Figure 6. (Continued.)

(figure $6 \mathrm{~h}$ ). The normative analyses of granitoids are plotted in $\mathrm{Q}-\mathrm{Ab}-\mathrm{Or}$ phase diagram (figure 6i) showing change in ternary eutectic and minimum compositions with variable water pressure, anorthite, boron, and fluoride contents (modified after Winter 2001). The compositions largely plot within worldwide granitic compositional field. The $\mathrm{K}_{2} \mathrm{O}-\mathrm{SiO}_{2}$ diagram suggests that these Mo-bearing granitoids belong to high$\mathrm{K}$ (Calc-alkaline) series. The $\mathrm{Na}_{2} \mathrm{O}-\mathrm{K}_{2} \mathrm{O}$ diagram used to discriminate I-, A- and S-type granitoids
(Collins et al. 1982) when employed for our Mo-bearing granitoids, indicate both I- and Atype affinity. The $\mathrm{Yb}-\mathrm{Ta}$ tectonic discrimination plot suggests these compositions to be volcanic arc granites (figure $6 \mathrm{j}$ ). The $\mathrm{Rb} / \mathrm{Sr}$ values range between 0.49 and $5.68 \quad(n=15$; avg. 1.95; SD $=1.50)$ suggesting the granitoids reached only low to moderate degree of fractionation. Hence, the K-feldspar-bearing granitoids from the ABC may have crystallized from a residual mafic melt after differential crystallization. The granitoids 
associated with Mo-mineralization have a high $\mathrm{Rb} / \mathrm{Sr}$ content (Plimer and Elliott 1979). The $\mathrm{SiO}_{2}-\mathrm{Rb} / \mathrm{Sr}$ (after Tischendorf and Pälchen 1985) suggests that these granitoids are in-situ formed crustal granitoids and occur in the W-Mo mineralized granite field of Raith (1995). The rock/primitive mantle normalized multicationic parameter diagram (after Sun and McDonough 1989; figure 6k) shows $\mathrm{Rb}, \mathrm{Ba}$, and $\mathrm{Pb}$ enrichment along with $\mathrm{K}$ whereas $\mathrm{Sr}$, Ti, and HREE are relatively depleted. The subduction-related crustal compositions are characteristically enriched in silica and LIL elements (K, U, and $\mathrm{Pb}$ ) and depleted in incompatible elements ( $\mathrm{Nb}, \mathrm{Ta}$, and $\mathrm{Ti}$ ) (Stern and Scholl 2013). In addition, the K-feldsparbearing granitoids with Bt are known to contain $\mathrm{Rb}$ and $\mathrm{Ba}$ in substantial amount and K-feldspar is a potential carrier of $\mathrm{Pb}$ (Ewart and Griffin 1994). Hydrothermal solutions can carry $\mathrm{Pb}$ as well and $\mathrm{Pb}$ can be highly mobile in metamorphic fluids (Wedepohl 1974). The normalised REE data (after Sun and McDonough 1989) of eight samples (table 3) show a LREE enriched and HREE depleted fractionated pattern with or without $\mathrm{Eu}$ anomaly (figure 61). This is consistent with the fractionated pattern shown by alkalifeldspar-bearing Bundelkhand granitoids, even though these samples have varied total REE concentrations.

\section{First data on fluid characteristic of Mo-bearing quartz grains and veins}

Four samples (BNS-84, BNS-106, BHU-1, and BGM-9) containing visible Mo intimately associated with quartz were studied for their fluid inclusion characteristics using a Linkam THMSG 600 heating-freezing stage mounted on a Leica (DMLM) digital polarizing microscope with camera attachment at the Department of Geology and Geophysics, IIT, Kharagpur. Inclusion petrography revealed presence of aqueous biphase inclusions as the most dominant type in all samples.

Aqueous-carbonic inclusions were observed in good numbers in samples BNS-84 and BNS-106 (figure $7 \mathrm{a}, \mathrm{b}$ ). Primary inclusions were well preserved with mild effects of later deformations (stretching of large inclusions). Non trail-bound moderate sized inclusions with regular shapes and away from healed cracks were chosen for microthermometry and the fluid inclusion data are summarized in figure $8(\mathrm{a}, \mathrm{b}, \mathrm{c}, \mathrm{d})$. In all, inclusions from all four samples together furnish a salinity range of $\sim 1$ to 31 wt. $\% \mathrm{NaCl}$ equivalent without a prominent mode, though salinity range of 1 to 4 wt.\% $\mathrm{NaCl}$ equivalent slightly outnumber inclusions in other ranges. There is a uniform representation of inclusions in the range of 4-24 wt. $\mathrm{NaCl}$ equivalent, classed at 4 wt.\% interval. This indicates a mixing trend between fluids of high and low salinities. Temperatures of homogenization obtained also vary between $100^{\circ}$ and $309^{\circ} \mathrm{C}$, again without a distinct mode. However, most homogenization temperatures are clustered between $150^{\circ}$ and $230^{\circ} \mathrm{C}$. A uniform representation of inclusions in all temperature intervals and clustering in a restricted range is corroborative evidence in favour of mixing of fluids. Paired salinity- $\mathrm{T}_{h}$ diagram also favours a mixing model with linear clustering parallel to the salinity axis. This trend indicates mixing of fluids of contrasting salinity without much of a contrast in their temperatures (figure 8c).

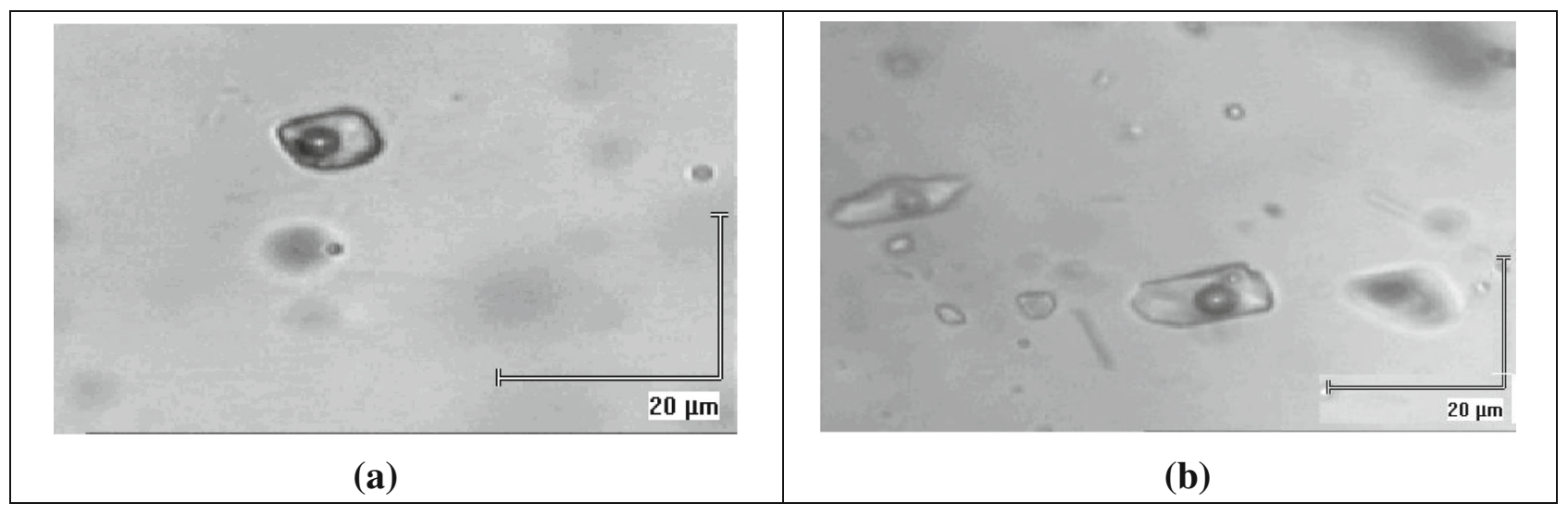

Figure 7. The aqueous biphase inclusions in two representative samples of Mo-bearing quartz veins. The samples are from BGM 9 (a) and BNS 106 (b), respectively. They all occur as part of the three dimensional network interpreted to be primary. Photographs show the inclusions in focus with others at different planes. The figures show more or less uniform fluid inclusion characteristics across samples in the area. 


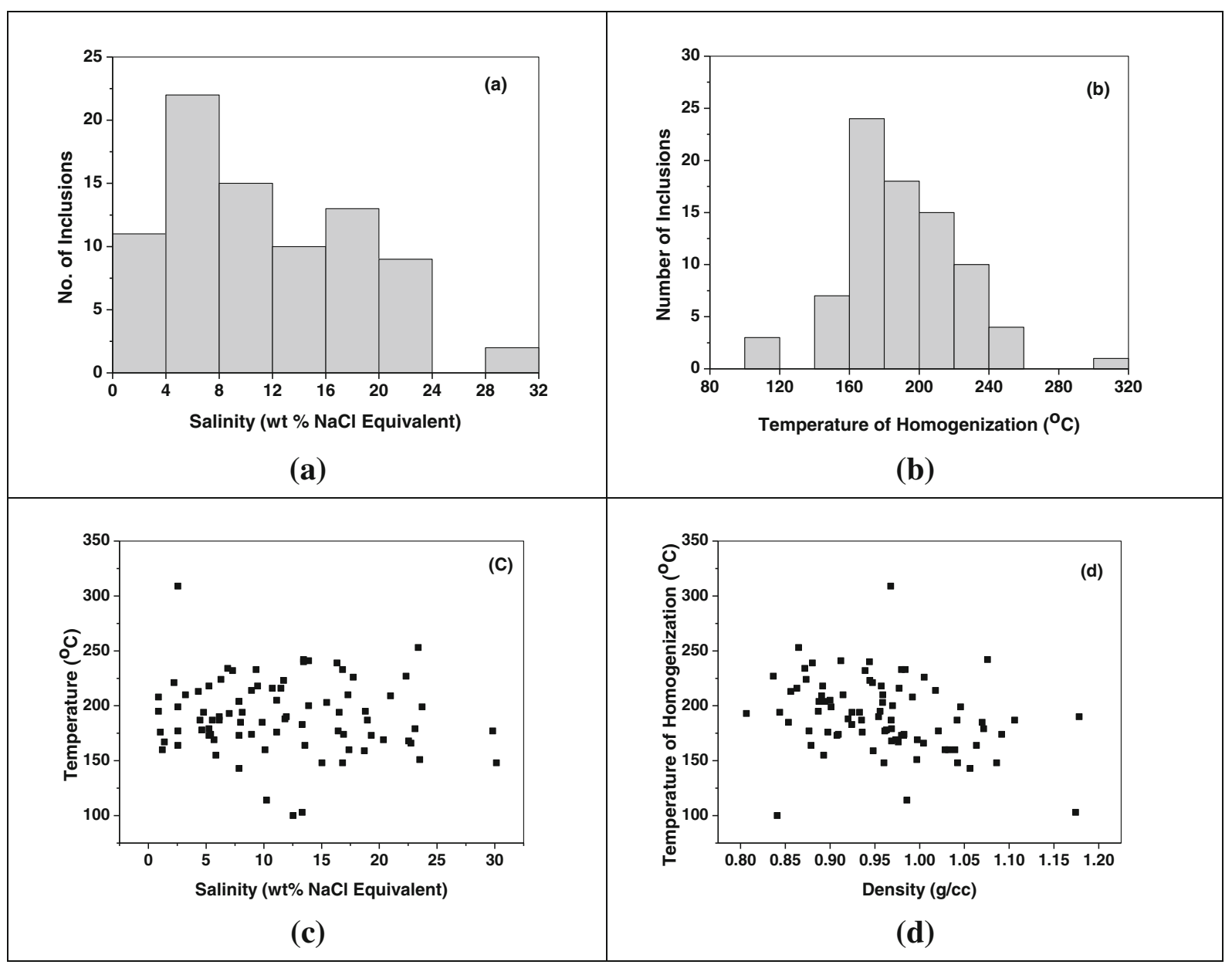

Figure 8. Characteristics of aqueous fluids associated with molybdenite mineralization in the study area. (a) Histogram of salinity in wt.\% $\mathrm{NaCl}$ equivalent; (b) histogram of temperature of homogenization; (c) fluid evolution diagram using temperature-salinity and (d) fluid evolution diagram using temperature density values.

There has been continued attempt to understand the hydrothermal geochemistry of molybdenum in relation to its transport and deposition. Keeping in view that the majority of Mo deposits are associated with granitic rocks, a strong affinity of the metal to felsic melts is expected. Isuk and Carman (1981) measured solubility of Mo in silicate melt and suggested that the metal is possibly carried in the melt as $\mathrm{MoSi}_{2} \mathrm{O}_{5}^{2+} / \mathrm{MoSi}_{2} \mathrm{O}_{6} /$ $\mathrm{MoSi}_{2} \mathrm{O}_{4}(\mathrm{OH})^{3+}$ species. However, since transport in fluid medium is a prerequisite for formation of its deposit, the mechanism of transport, or more specifically, the complexing ligand must be understood. Unlike copper (the metal with which it is closely associated) which has a strong affinity for chloride ion, molybdenum is known to form oxyhydroxo complexes (Candela and Holland 1984) and the concentration of Mo is understood to be independent of chloride content of the fluid. Webster (1997) determined the apparent melt versus fluid partition coefficient of 8-80 for molybdenum as a function of $\mathrm{NaCl}+\mathrm{KCl}$ content of fluid, yet suggested that Mo is not transported as chloride complex. Ulrich and Mavrogenes (2008) observed that the type of complexing varies with fluid chemistry. They suggested that Mo could be transported either as $(\mathrm{K} / \mathrm{Na}) \mathrm{HMoO}_{4}$ or $\mathrm{MoO}_{2} \mathrm{Cl}^{+} /$ $\mathrm{MoO}_{2} \mathrm{Cl}_{2} / \mathrm{MoO}_{2} \mathrm{Cl}_{3}^{-}$(depending on the $\mathrm{Cl}^{-}$concentrations) in fluids with high to moderately high salinity. In low saline water rich fluid, the Mo transport efficiency is reduced although $\mathrm{H}_{2} \mathrm{MoO}_{4}$ type species could still be present. Such a mode of transport is in good agreement with the present study in which a Na-K-rich host pluton would have initially carried molybdenum. On magmatichydrothermal transition, the $\mathrm{K}-\mathrm{Na}$-rich fluid, represented by the moderate to high saline fluid would have continued transporting Mo and deposited in response to mixing with low-saline fluid. Panigrahi and Mookherjee (1997) also suggested transport of both $\mathrm{Cu}$ and $\mathrm{Mo}$ in the same fluid and concluded deposition as a result of mixing of fluids. 
Table 4. The representative major, trace and REE analyses of Mo-bearing rocks of the ABC. Major element analyses are in weight \% and trace elements including REEs are in ppm.

\begin{tabular}{|c|c|c|c|c|c|c|c|c|c|c|c|c|}
\hline Sample/oxide & BM-1 & BM-2 & BM-3 & BM-4 & BM-5 & BM-6 & BM-7 & BM-8 & BM-9 & BM-10 & BM-11 & BM-12 \\
\hline $\mathrm{SiO}_{2}$ & 74.32 & 75.57 & 75.64 & 75.72 & 70.44 & 76.41 & 70.36 & 76.18 & 74.51 & 73.41 & 74.49 & 75.77 \\
\hline $\mathrm{TiO}_{2}$ & 0.10 & 0.02 & 0.11 & 0.07 & 0.19 & 0.07 & 0.07 & 0.04 & 0.11 & 0.03 & 0.12 & 0.04 \\
\hline $\mathrm{Al}_{2} \mathrm{O}_{3}$ & 13.22 & 13.29 & 13.32 & 12.93 & 14.3 & 12.93 & 14.75 & 12.31 & 12.6 & 13.20 & 12.30 & 12.6 \\
\hline $\mathrm{Fe}_{2} \mathrm{O}_{3}$ & 1.83 & 0.47 & 1.54 & 1.25 & 3.70 & 1.25 & 2.70 & 1.11 & 1.30 & 0.85 & 0.92 & 0.79 \\
\hline $\mathrm{MnO}$ & 0.02 & 0.01 & 0.01 & 0.01 & 0.04 & 0.01 & 0.01 & 0.01 & 0.02 & 0.01 & 0.02 & 0.01 \\
\hline $\mathrm{MgO}$ & 0.40 & 0.11 & 0.65 & 0.18 & 1.12 & 0.18 & 1.04 & 0.22 & 0.86 & 0.51 & 0.57 & 0.48 \\
\hline $\mathrm{CaO}$ & 0.35 & 0.65 & 0.25 & 1.13 & 2.20 & 1.13 & 1.30 & 0.63 & 0.40 & 0.26 & 0.44 & 0.39 \\
\hline $\mathrm{Na}_{2} \mathrm{O}$ & 3.97 & 3.47 & 3.74 & 4.60 & 4.44 & 4.60 & 4.66 & 3.87 & 3.27 & 3.08 & 3.27 & 2.93 \\
\hline $\mathrm{K}_{2} \mathrm{O}$ & 4.84 & 6.19 & 4.59 & 3.32 & 1.93 & 3.32 & 3.56 & 5.09 & 4.70 & 5.70 & 4.80 & 6.00 \\
\hline $\mathrm{P}_{2} \mathrm{O}_{5}$ & 0.11 & 0.02 & 0.07 & 0.01 & 0.27 & 0.01 & 0.27 & 0.01 & 1.40 & 1.58 & 2.19 & 0.09 \\
\hline LOI & 0.47 & 0.55 & 0.33 & 0.56 & 0.97 & 0.56 & 1.43 & 0.65 & 0.59 & 1.26 & 0.89 & 0.36 \\
\hline Total & 99.63 & 100.33 & 100.25 & 99.78 & 99.6 & 100.47 & 100.15 & 100.12 & 99.76 & 99.89 & 100.01 & 99.46 \\
\hline $\mathrm{V}$ & n.d. & $<10$ & $<10$ & $<10$ & 34 & 29 & 43 & 26 & $<10$ & $<10$ & $<10$ & 27 \\
\hline $\mathrm{Cr}$ & 3.6 & 11 & $<10$ & $<10$ & 28 & 27 & 20 & 17 & $<10$ & $<10$ & $<10$ & 17 \\
\hline $\mathrm{Co}$ & 1.8 & $<5$ & $<5$ & $<5$ & $<5$ & $<5$ & 7 & $<5$ & $<5$ & $<5$ & $<5$ & 5 \\
\hline $\mathrm{Ni}$ & 20 & 20 & 20 & 23 & 27 & 26 & 23 & 23 & 20 & 18 & 20 & 27 \\
\hline $\mathrm{Cu}$ & $<10$ & 7 & 13 & 11 & 11 & 11 & 11 & 22 & 6 & 9 & 8 & 5 \\
\hline $\mathrm{Zn}$ & 15 & 27 & 25 & 25 & 53 & 46 & 70 & 42 & 24 & 21 & 24 & 50 \\
\hline $\mathrm{Rb}$ & n.d. & 180 & 210 & 155 & 170 & 155 & 135 & 160 & 245 & 235 & 220 & 165 \\
\hline $\mathrm{Sr}$ & n.d. & 87 & 99 & 99 & 150 & 146 & 275 & 184 & 114 & 96 & 124 & 156 \\
\hline $\mathrm{Y}$ & n.d. & $<20$ & 32 & $<20$ & 32 & 26 & 20 & $<20$ & 33 & 27 & 33 & 25 \\
\hline $\mathrm{Zr}$ & n.d. & 139 & 150 & 147 & 285 & 269 & 331 & 246 & 189 & 119 & 185 & 258 \\
\hline $\mathrm{Nb}$ & n.d. & 28 & 34 & 29 & 31 & 30 & 24 & 27 & 31 & 35 & 31 & 30 \\
\hline La & 25 & 14 & 27 & 45 & 80 & 60 & 22 & 33 & n.d. & n.d. & n.d. & n.d. \\
\hline $\mathrm{Ce}$ & 32 & 20 & 64 & 80 & 119 & 100 & 37 & 17 & n.d. & n.d. & n.d. & n.d. \\
\hline $\mathrm{Sm}$ & 2.5 & 1.6 & 4.1 & 4.5 & 5.5 & 5.2 & 3.2 & 2.2 & n.d. & n.d. & n.d. & n.d. \\
\hline $\mathrm{Nd}$ & 11 & 8.4 & 22 & 37 & 36 & 38 & 15 & 9 & n.d. & n.d. & n.d. & n.d. \\
\hline $\mathrm{Eu}$ & 0.73 & 0.51 & 0.52 & 1.33 & 1.1 & 1.7 & 0.66 & 0.7 & n.d. & n.d. & n.d. & n.d. \\
\hline $\mathrm{Tb}$ & 0.38 & 0.14 & 0.64 & 0.57 & 0.52 & 0.75 & 0.52 & 0.38 & n.d. & n.d. & n.d. & n.d. \\
\hline $\mathrm{Yb}$ & 0.69 & 0.35 & 1.1 & 0.51 & 0.94 & 1 & 0.61 & 1 & n.d. & n.d. & n.d. & n.d. \\
\hline \multirow[t]{2}{*}{$\mathrm{Lu}$} & 0.09 & 0.05 & 0.12 & 0.05 & 0.12 & 0.19 & 0.08 & 0.1 & n.d. & n.d. & n.d. & n.d. \\
\hline & BM-13 & BM-14 & BM-15 & BM-16 & BM-17 & BM-18 & BM-19 & BM-20 & BM-21 & BM-22 & BM-23 & \\
\hline $\mathrm{SiO}_{2}$ & 75.60 & 75.85 & 76.10 & 73.52 & 72.73 & 68.18 & 73.32 & 75.79 & 76.29 & 75.80 & 74.40 & \\
\hline $\mathrm{TiO}_{2}$ & 0.12 & 0.07 & 0.10 & 0.28 & 0.25 & 0.44 & 0.24 & 0.14 & 0.06 & 0.14 & 0.23 & \\
\hline $\mathrm{Al}_{2} \mathrm{O}_{3}$ & 12.30 & 11.70 & 12.00 & 12.30 & 12.50 & 14.60 & 12.40 & 11.90 & 12.10 & 12.20 & 12.50 & \\
\hline $\mathrm{Fe}_{2} \mathrm{O}_{3}$ & 1.10 & 0.89 & 1.00 & 3.10 & 2.80 & 4.60 & 2.60 & 1.10 & 1.00 & 1.00 & 2.60 & \\
\hline $\mathrm{MnO}$ & 0.02 & 0.02 & 0.02 & 0.05 & 0.05 & 0.08 & 0.05 & 0.02 & 0.02 & 0.02 & 0.05 & \\
\hline $\mathrm{MgO}$ & 0.73 & 0.61 & 0.53 & 0.69 & 0.84 & 1.00 & 0.80 & 0.39 & 1.00 & 0.55 & 0.49 & \\
\hline $\mathrm{CaO}$ & 0.29 & 0.47 & 0.47 & 1.80 & 1.60 & 3.30 & 1.70 & 0.15 & 0.77 & 0.51 & 1.90 & \\
\hline $\mathrm{Na}_{2} \mathrm{O}$ & 3.00 & 3.26 & 3.12 & 3.26 & 3.26 & 3.88 & 3.31 & 2.68 & 3.00 & 3.05 & 3.44 & \\
\hline $\mathrm{K}_{2} \mathrm{O}$ & 5.30 & 4.90 & 4.90 & 3.80 & 3.90 & 2.60 & 3.70 & 5.60 & 5.10 & 5.50 & 3.30 & \\
\hline $\mathrm{P}_{2} \mathrm{O}_{5}$ & 0.89 & 0.92 & 0.79 & 0.63 & 0.64 & 1.21 & 0.61 & 0.93 & 0.91 & 0.87 & 0.56 & \\
\hline LOI & 0.68 & 0.75 & 0.90 & 0.51 & 0.94 & 0.93 & 0.78 & 0.86 & 0.28 & 0.52 & 0.75 & \\
\hline Total & 100.03 & 99.44 & 99.93 & 99.94 & 99.51 & 100.82 & 99.51 & 99.56 & 99.53 & 100.16 & 100.00 & \\
\hline $\mathrm{V}$ & $<10$ & $<10$ & $<10$ & 34 & 29 & 43 & 26 & $<10$ & $<10$ & $<10$ & 27 & \\
\hline $\mathrm{Cr}$ & 11 & $<10$ & $<10$ & 28 & 27 & 20 & 17 & $<10$ & $<10$ & $<10$ & 17 & \\
\hline $\mathrm{Co}$ & $<5$ & $<5$ & $<5$ & $<5$ & $<5$ & 7 & $<5$ & $<5$ & $<5$ & $<5$ & 5 & \\
\hline $\mathrm{Ni}$ & 20 & 20 & 23 & 27 & 26 & 23 & 23 & 20 & 18 & 20 & 27 & \\
\hline $\mathrm{Cu}$ & 7 & 13 & 11 & 11 & 11 & 11 & 22 & 6 & 9 & 8 & 5 & \\
\hline $\mathrm{Zn}$ & 27 & 25 & 25 & 53 & 46 & 70 & 42 & 24 & 21 & 24 & 50 & \\
\hline $\mathrm{Rb}$ & 180 & 210 & 155 & 170 & 155 & 135 & 160 & 245 & 235 & 220 & 165 & \\
\hline
\end{tabular}

n.d.: not determined. 
Table 4. (Continued.)

\begin{tabular}{lcrrrrrrrrrr}
\hline Sample/oxide & BM-13 & BM-14 & BM-15 & BM-16 & BM-17 & BM-18 & BM-19 & BM-20 & BM-21 & BM-22 & BM-23 \\
\hline Sr & 87 & 99 & 99 & 150 & 146 & 275 & 184 & 114 & 96 & 124 & 156 \\
$\mathrm{Y}$ & $<20$ & 32 & $<20$ & 32 & 26 & 20 & $<20$ & 33 & 27 & 33 & 25 \\
$\mathrm{Zr}$ & 139 & 150 & 147 & 285 & 269 & 331 & 246 & 189 & 119 & 185 & 258 \\
$\mathrm{Nb}$ & 25 & 34 & 29 & 31 & 30 & 24 & 27 & 31 & 35 & 31 & 30 \\
\hline
\end{tabular}

\section{Conclusions}

The mesoscopic, microscopic and submicroscopic physico-chemical characterization of metallic phases confirm the presence of molybdenite with or without $\mathrm{Py} \pm \mathrm{Ccp} \pm \mathrm{Bn} \pm \mathrm{Gn} \pm \mathrm{Sp} \pm$ Ep \pm Cal. The Mo-bearing rock types include granite pegmatite, granite, granodiorite and TTG gneisses, mainly. The mineralization is mostly associated with sheared granitoids and predominantly occurs along/around the Bundelkhand Tectonic Zone and Raksa Shear Zone coinciding largely with the trend observed in case of gold mineralization earlier reported (Pati et al. 1997) from the ABC. The granitoid geochemistry suggests that the Mo-bearing rocks are high-K, metaluminous to peraluminous, moderately fractionated, volcanic arc-generated, I- and A-type granitoids and occur in the W-Mo mineralized granite field of Raith (1995). The porphyry $\mathrm{Cu}-\mathrm{Mo}$ mineralization is generally known to be associated with metaluminous granitoids (McMillan and Panteleyev 1980) similar to the Mo-bearing granitoids of the ABC. The Mo mineralization in granitoids mainly occurs in the form of specks, disseminated type, clots, stringers, solution seams, and as films. The Mo (visible and invisible) with or without other sulphides occurring along the shear planes as films, fault traces, intrusion lobes and pegmatite veins, and different granitoid variants suggest the mineralization to be a polyphase temporal event although the chronological data is currently unavailable.

The first fluid inclusion data from different sample types and areas obtained during the present study indicate a dominantly aqueous hypersaline fluid homogenized at moderate temperatures $\left(100-300^{\circ} \mathrm{C}\right)$ advocating a possible hydrothermal origin for the Mo-bearing quartz vein although more microthermometric data are needed to address the issue of molybdenum transport and deposition. Varied fluid types, mixing, and different homogenization temperatures also support multiple phases of mineralization in contrasting thermo-tectonic settings in parts of the ABC.

\section{Acknowledgements}

JKP acknowledges the GSI, Govt. of India as part of this work was completed during his tenure there. The authors thank the reviewers for their constructive comments and suggestions.

\section{References}

Basu A K 1986 Geology of parts of the Bundelkhand Granite Massif, Central India; Rec. Geol. Surv. India 101 61-124.

Candela P A and Holland H D 1984 The partitioning of copper and molybdenum between silicate melts and aqueous fluids; Geochim. Cosmochim. Acta 48 343-380.

Collins W J, Beams S D, White A J R and Chappell B W 1982 Nature and origin of A type granites with particular reference to southeastern Australia; Contrib. Mineral. Petrol. 80 189-200.

Corbett G J and Leach T M 1998 Southwest Pacific Rim Gold-Copper Systems: Structure, alteration, and mineralization; Soc. Econ. Geol. Spec. Publ. 237.

Delibaş O and Genç Y 2012 Re-Os molybdenite ages of granitoid-hosted $\mathrm{Mo}-\mathrm{Cu}$ occurrences from central Anatolia (Turkey); Ore Geol. Rev. 44 39-48.

Ewart A and Griffin W L 1994 Application of protonmicroprobe data to trace-element partitioning in volcanicrocks; Chem. Geol. 117 251-284.

Gokarn S G, Rao C K, Selvaraj C, Gupta G and Singh B P 2013 Crustal evolution and tectonics of the Archean Bundelkhand craton, central India; J. Geol. Soc. India 82 455-460.

Hou Z Q, Yang Z M, Qu X M, Meng X J, Li Z Q, Beaudoin G, Rui Z Y, Gao Y F and Zaw K 2009 The Miocene Gangdese porphyry copper belt generated during postcollisional extension in the Tibetan Orogen; Ore Geol. Rev. 36 25-51.

Isuk E and Carman $\mathrm{J}$ H 1981 The system $\mathrm{Na}_{2} \mathrm{Si}_{2} \mathrm{O}_{5}-$ $\mathrm{K}_{2} \mathrm{Si}_{2} \mathrm{O}_{5}-\mathrm{MoS}_{2}-\mathrm{H}_{2} \mathrm{O}$ with implications for molybdenum transport in silicate melts; Econ. Geol. 76 2222-2235.

Li N, Chen Y J, Fletcher I R and Zeng P S 2011 Triassic mineralization with Cretaceous overprint in the Dahu $\mathrm{Au}-\mathrm{Mo}$ deposit, Xiaoqinling gold province: Constraints from SHRIMP monazite U-Th-Pb geochronology; Gondwana Res., doi: 10.1016/j.gr.2010.12.013.

Malviya V P, Arima M, Pati J K and Kaneko Y 2006 Petrology and geochemistry of metamorphosed basaltic pillow lava and basaltic komatiite in Mauranipur area: Subduction related volcanism in Archean Bundelkhand craton, central India; J. Mineral. Petrol. Sci. 101 199217.

Maniar P D and Piccoli P M 1989 Tectonic discrimination of granitoids; Geol. Soc. Am. Bull. 101 635-643.

Mao J W, Zhang Z C, Zhang Z H and Du A D 1999 Re-Os dating of molybdenites in the Xiaoliugou W(Mo) deposit in the northern Qilian Mountains and its geological significances; Geochim. Cosmochim. Acta 63 1815-1818.

McMillan W T and Panteleyev A 1980 Ore deposit models-1, Porphyry copper deposits; Geosci. Canada 7 52-63.

Mondal M E A and Ahmad T 2001 Bundelkhand mafic dykes, central Indian shield: Implication for the role of sediment subduction in Proterozoic crustal evolution; Island Arc. 10 51-67.

Mondal M E A, Goswami J N, Deomurari M P and Sharma K K 2002 Ion microprobe ${ }^{207} \mathrm{~Pb} /{ }^{206} \mathrm{~Pb}$ ages zircons from 
Bundelkhand massif, north India: Implications for crustal evolution of the Bundelkhand-Aravalli protocontinent; Precamb. Res. 117 85-100.

Nim S P and Hasan S S 1997 Specialized thematic studies of Bundelkhand granitoids for appraisal of the mode of occurrence of molybdenum and associated mineralization, Banda-Akbarpur-Pangara area, Banda districts, U.P.; Geol. Surv. India Records 129 142-144.

Panigrahi M K and Mookherjee A 1997 The Malanjkhand copper (+molybdenum) deposit, India: Mineralization from a low temperature ore-fluid of granitoid affiliation; Miner. Deposita 32 133-148.

Panigrahi M K, Mookherjee A, Pantulu G V C and Gopalan K 1993 Granitoids around Malanjkhand copper deposit: Types and age relationship; Proc. Indian Acad. Sci.(Earth Planet. Sci.) 102 399-413.

Pandit D and Panigrahi M K 2012 Comparative petrogenesis and tectonics of paleoproterozoic Malanjkhand and Dongargagh granitoids, central India; J. Asian Earth Sci. 50 14-26.

Pathak M, Gupta S, Bhattacharya S, Rao M K and Bhaumik B K 2009 Mapping the inhomogeneity of the $\mathrm{U}$ and Th distributions - using sample size concept in the field conditions; Indian J. Phys. 83(7) 993-1000.

Pati J K 1997 Specialized thematic studies of Bundelkhand granitoids for appraisal of the mode of occurrence of molybdenum and associated mineralization, Rauli Kalyanpur area, Banda districts, U.P.; Geol. Surv. India Records 129 144-146.

Pati J K 1998 Specialized thematic studies of Bundelkhand Granitoids Complex, southern U.P.; Geol. Surv. India Rec. 130 88-89.

Pati J K 1999 Study of granitoid mylonites and reef/ vein quartz in parts of Bundelkhand Granitoid Complex (BGC); Geol. Surv. India Rec. 131(8) 95-96.

Pati J K and Panigrahi M K 2005 Molybdenite-bearing granitoids from Bundelkhand craton and the nature of mineralising fluid; National Seminar on Proterozoic Systems of India: Evolution and Economic Potential (Indian School of Mines Dhanbad), Abstract Volume, 30.

Pati J K, Raju S, Mamgain V D and Shankar R 1997 Record of gold mineralization in parts of Bundelkhand Granitoid Complex (BGC); J. Geol. Soc. India 50 601-606.

Pati J K, Patel S C, Pruseth K L, Malviya V P, Arima M, Raju S, Pati P and Prakash K 2007 Geochemistry of giant quartz veins from the Bundelkhand craton, central India and their implications; J. Earth Syst. Sci. 116 497-510.

Pati J K, Reimold W U, Koeberl C and Pati P 2008a The Dhala Structure, Bundelkhand Craton, central India - eroded remnant of a large Paleoproterozoic impact structure; Meteoritics Planet. Sci. 43 1383-1398.

Pati J K, Raju S, Malviya V P, Bhushan R, Prakash K and Patel S C 2008b Mafic dykes of Bundelkhand Craton, central India: Field, petrological and geochemical characteristics; In: Indian Dykes: Geochemistry, Geophysics and Geochronology (eds) Srivastava R et al. (New Delhi: Narosa Publishing House), pp. 547-569.

Pati J K, Jourdan F, Armstrong R A, Reimold W U and Prakash K 2010 First SHRIMP U-Pb and ${ }^{40} \mathrm{Ar} /{ }^{39} \mathrm{Ar}$ chronological results from impact melt breccia from the Paleoproterozoic Dhala impact structure, India; In: Large Meteorite Impacts and Planetary Evolution IV (eds) Reimold W U and Gibson R L Geol. Soc. Am. Spec. Paper 465 571-591, doi: 101130/2010.2465(27).

Pearce J A, Harris N B W and Tindle A G 1984 Trace element discrimination diagrams for the tectonic interpretation of granitic rocks; J. Petrol. 25 956-983.

Plimer I R and Elliott S M 1979 The use of Rb/Sr ratios as a guide to mineralization; J. Geochem. Explor. 12 21-34.
Pouchou J L and Pichoir F 1985 "PAP" ( $\Phi-\varphi-z)$ correction produce for improved quantitative microanalysis; In: Microbeam Analysis, Armstrong J T (ed.) San Francisco Press, San Francisco, pp. 104-106.

Rahaman A and Zainuddin S M 1993 Bundelkhand granite: An example of collision-related Precambrian magmatism and its relevance to the evolution of the central Indian shield; J. Geol. 101 413-419.

Raith J G 1995 Petrogenesis of the Concordia Granite Gneiss and its relation to W-Mo mineralization in western Namaqualand, South Africa; Precamb. Res. 70 303-335.

Rao M J, Rao P G V S, Widdowson M and Kelley S P 2005 Evolution of Proterozoic mafic dyke swarms of Bundelkhand craton, central India; Curr. Sci. 88 502506.

Richards J P 2003 Tectono-magmatic precursors for porphyry $\mathrm{Cu}-(\mathrm{Mo}-\mathrm{Au})$ deposit formation; Econ. Geol. 98 1515-1533.

Saha L, Pant N C, Pati J K, Upadhyay D, Berndt J, Bhattacharya A and Satyanarayanan A 2010 Neoarchean high-pressure margarite-phengitic muscovite-chlorite corona mantled corundum in quartz-free high- $\mathrm{Mg}, \mathrm{Al}$ phlogopite-chlorite schists from the Bundelkhand craton, north central India; Contrib. Mineral. Petrol., doi: 10.1007/s00410-010-0546-7.

Santosh M 1988a Granite-molybdenite system of Ambalavayal, Kerala. Part-I: Geochemistry and petrogenesis of the granite; J. Geol. Soc. India 32 83-105.

Santosh M 1988b Granite-molybdenite system of Ambalavayal, Kerala. Part-II: Nature of mineralization, sulfur isotopes, fluid characteristics and genetic model; J. Geol. Soc. India 32 191-213.

Santosh M 1999 A molybdenum province in the East Gondwana fragment of southern India; Gondwana Res. 2 606-607.

Sarkar A, Trivedi J R, Gopalan K, Singh P N, Das A K and Paul D K 1984 Rb-Sr geochronology of the Bundelkhand Granite Complex in the Jhansi-Babina-Talbehat sector, UP, India; J. Earth Sci. (CEISM Volume), pp 64-72.

Sarkar A, Bhalla J K, Bishui P K, Gupta S N, Singhai R K and Upadhaya T P 1994 Tectonic discrimination of granitic rocks: Studies on the early Proterozoic Bundelkhand Complex, central India; Indian Minerals $\mathbf{4 5}$ 103-112.

Sarkar A, Paul D K and Potts P J 1996 Geochronology and geochemistry of mid-Archaean trondhjemitic gneiss from the Bundelkhand craton, central India; Rec. Res. Geol. 16 76-92.

Sharma R P 1979 Origin of the pyrophyllite-diaspore deposits of the Bundelkhand Complex, central India; Miner. Deposita 14 343-352.

Sharma K K and Rahman A 1995 Occurrence and petrogenesis of Loda Pahar trondhjemitic gneiss from Bundelkhand craton, central India: Remnant of an early crust; Curr. Sci. 69 613-617.

Shukla R S and Singh D P 1997 Specialized thematic studies of Bundelkhand granitoids for appraisal of the mode of occurrence of molybdenum and associated mineralization, Naraini-Kartal-Girdharpur-Bhawanipur area, Banda districts, UP; Geol. Surv. India Rec. 129 141-142.

Senthiappan M 1976 Geology of the area along the Raksa Shear zone, Jhansi district, Uttar Pradesh, Symposium on the Archaean of the Central India, GSI, Nagpur, November 30-December 1 (Abstract).

Senthiappan M 1981 Geology of the area along the Raksa Shear zone, Jhansi district, Uttar Pradesh; Geol. Surv. India Spec. Publ. 3 73-76. 
Sillitoe R H 1972 A plate tectonic model for the origin of porphyry copper deposits; Econ. Geol. 67 184-197.

Stein H J 2006 Low-rhenium molybdenite by metamorphism in northern Sweden: Recognition, genesis, and global implications; Lithos 87 300-327.

Stein H J, Markey R J and Morgan J W 1997 Highly precise and accurate Re-Os ages for molybdenite from the East Qinling molybdenum belt, Shaanxi Province, China; Econ. Geol. 92 827-835.

Stein H J, Hannah J L, Zimmerman A, Markey R J, Sarkar $\mathrm{S} \mathrm{C}$ and Pal A B 2004 A 2.5 Ga porphyry $\mathrm{Cu}-\mathrm{Mo}-\mathrm{Au}$ deposit at Malanjkhand, central India: Implications for Late Archean continental assembly; Precamb. Res. 134 189-226.

Stern R J and Scholl D W 2013 Yin and yang of continental crust creation and destruction by plate tectonic processes; Int. Geol. Rev. 52(1) 1-31.

Sun S S and McDonough W F 1989 Chemical and isotopic systematics of oceanic basalts: Implications for mantle composition and processes; Geol. Soc. London Spec. Publ. $42313-345$.

Tischendorf G and Pälchen W 1985 Zur Klassifikation von Granitoiden; Z. Geol. Wiss. 13 615-627.

Ulrich T and Mavrogenes J 2008 An experimental study of the solubility of molybdenum in $\mathrm{H}_{2} \mathrm{O}$ and $\mathrm{KCl}-\mathrm{H}_{2} \mathrm{O}$ solutions from $500-800^{\circ} \mathrm{C}$, and 150 to $300 \mathrm{MPa}$; Geochim. Cosmochim. Acta 72 2316-2330.

Webster J D 1997 Exsolution of magmatic volatile phases from $\mathrm{Cl}$ enriched mineralized granitic magmas and implications for ore metal transport; Geochim. Cosmochim. Acta 61 1017-1029.

Wedepohl K H 1974 Handbook of Geochemistry; SpringerVerlag, Berlin.

Whitney D L and Evans B W 2010 Abbreviations for names of rock-forming minerals; Am. Mineral. 95 185-187.

Winter J D 2001 An Introduction to Igneous and Metamorphic Petrology (New Jersey: Prentice Hall), $697 \mathrm{p}$. 